\title{
The Influence of Product Quality and Price on Purchasing Decisions at Mitraindo South Tangerang Online Shop
}

\author{
Mada Faisal Akbar \\ Universitas Pamulang \\ E-mail: dosen02471@unpam.ac.id
}

\begin{abstract}
This study aims to determine the effect of product quality and price on purchasing decisions at Mitraindo South Tangerang Online Shop. The method used is explanatory research with analytical techniques using statistical analysis with regression testing, correlation, determination, and hypothesis testing. The results of this study product quality significantly influence purchasing decisions by 40.3, the hypothesis test obtained $t_{\text {count }}>t_{\text {table }}$ or $(7.974>1.986)$. Price significantly influences the purchase decision of $38.0 \%$, the hypothesis test is obtained $t_{\text {count }}>t_{\text {table }}$ or $(7.594>1.986)$. Product quality and price simultaneously have a significant effect on purchasing decisions of $49.0 \%$, the hypothesis test is obtained $F_{\text {count }}>F_{\text {table }}$ or $(44,626>2,700)$
\end{abstract}

Keywords: Product quality, price, purchase decision.

\section{INTRODUCTION}

In the 2000s until now, online shopping systems have continued to develop throughout the world and even in Indonesia. This is certainly supported by the increasing number of internet users both in big cities and regions (Maulana, Susilo, \& Riyadi, 2015; Putra \& Santoso, 2013; Rahmawati \& Mulyono, 2016). Online business is known as Electronic Commerce (ecommerce), namely buying, selling, marketing of goods and services through electronic systems such as the internet and television. Ecommerce also involves transfers and electronics, electronic data exchanges, automated inventory management systems, and automated data collection systems (Peterson, 2000; Walch, 2009). The development of increasingly rapid and sophisticated technology becomes a challenge for business people and encourages business people to be able to master technology, in addition to that business people must be able to adjust to customers and have quality goods because in marketing activities customers and goods play an important role, which means that in purchasing decisions and product quality is in the hands of customers.

Product quality according to (Kotler, 2013), product quality suggests that quality is the overall characteristics and nature of a product or service that affects its ability to satisfy expressed or implied needs. Product quality according to (Kotler, P. \& Armstrong, 2008), the ability of a product to demonstrate its function, this includes the overall durability, reliability, accuracy, ease of operation, and product repairs, as well as other product attributes.

One aspect that is also a consideration of consumers in buying a product is also the price factor, where consumers often compare prices with other competitors which are cheaper but also the product is no less competitive. Product price is the sum of all values given by customers to benefit from owning or using a product or service (Laussel, Long, \& Resende, 2020; Li, 
238| Jurnal Administrare: Jurnal Pemikiran Ilmiah dan Pendidikan Administrasi Perkantoran

Volume 6 Number 2 July- December 2019. Pages 237-248

Nagurney, \& Yu, 2018; Nair, 2019). According to (Tjiptono, 2007), the price of a product is a monetary unit or another measure including other goods and services exchanged in order to obtain ownership rights or users of an item and service. Companies need to continue to improve the quality of products or services and provide variations in product prices because increasing product quality and product price variations can make consumers feel satisfied with the products or services they buy and will influence consumers to make repeat purchases (Dinopoulos, Kalyvitis, \& Katsimi, 2020; Ferrara, Missios, \& Yildiz, 2019; Narwal \& Nayak, 2020).

The purchase decision is an action taken by consumers to choose one of several alternative choices in buying a product in the form of goods or services (Dabhilkar, 2011; Ritnamkam \& Sahachaisaeree, 2012; Sheats, Middlestadt, Ona, Juarez, \& Kolbe, 2013). In purchasing decisions, every consumer has a strategy to get superior products in accordance with satisfaction and desires. According to (Kotler \& Keller, 2015), buying decision is process all the experiences in learning, choosing, using, and event disposing of a product.. According to (Kotler dan Amstrong, 2008) is to give the most preferred brand, but two factors can be between purchase intention and purchase decision.

The existence of purchasing decisions affect the number of sales decline because consumers have their own attraction in choosing the goods provided, along with data on the number of sales decline in the period 2016-2018, as follows. A store in releasing its products should be in accordance with the wishes of the customer. That way the product can compete in the market, thus making customers have many alternative products before making their decision. If the product quality is good and the price of the product is in accordance with the quality, the company's image will be good in the eyes of customers and influence purchasing decisions (Amrullah \& Agustin, 2016; Lubis \& Hidayat, 2017; Prasastiningtyas, 2016).

The existence of sales purchase decisions at Mitraindo Online Shop affects customer data that has decreased, this can be seen from the table of the period 2016 to 2018 :

Table 1.

Customer Data for the Period of 2016 to 2018

\begin{tabular}{|c|c|c|c|}
\hline Month & In 2016 & In 2017 & In 2018 \\
\hline January & 243 & 155 & 136 \\
\hline February & 277 & 198 & 180 \\
\hline March & 387 & 245 & 279 \\
\hline April & 310 & 255 & 280 \\
\hline May & 198 & 298 & 293 \\
\hline June & 131 & 312 & 315 \\
\hline July & 110 & 167 & 114 \\
\hline August & 118 & 243 & 97 \\
\hline September & 102 & 254 & 86 \\
\hline October & 71 & 265 & 79 \\
\hline November & 62 & 122 & 142 \\
\hline December & 76 & 115 & 126 \\
\hline Total & 2.285 & 2.631 & 2.127 \\
\hline
\end{tabular}


Based on table 1, it is known that from 2015 to 2017 there was a decrease in customers, the decrease in the number of customers at Mitraindo online shop above was caused by the product quality and product prices given to customers. According to (Kotler, 2013) the purchase decision is a purchase decision process consisting of five stages carried out by a consumer before arriving at the purchase decision and subsequently on purchasing.

\section{METHOD}

The type of research used is associative, where the aim is to find out the connection between. A population is a group of objects that are determined through certain criteria that will be categorized into objects that will be examined. According to (Sugiyono, 2010) defines the population is the number of generalization areas consisting of objects or subjects that have the quality and characteristics determined by researchers and then drawn conclusions. The population in the study amounted to 96 respondents Shop South Tangerang Mitraindo Shop. According to Sugiyono (2016) that is, the sample is the number and characteristics possessed by the population. While (Arikunto, 2006) argues that, the sample is part or representative of the population under study. The sampling technique in this study is saturated sampling, where all members of the population are sampled. Thus the sample in this study amounted to 96 respondents. In analyzing the data used the instrument test, classical assumption test, regression, coefficient of determination, and hypothesis testing.

\section{RESULT AND DISCUSSION}

Mitraindo Shop is an Online Shop in the city of South Tangerang is an E-commerce for the category of roofing products made from polycarbonate. Mitraindo Shop Online shop was established on August 24, 2011, until today. Mitraindo Online Shop is an online shop that sells various types of polycarbonate roofs including Twinlite, Solarlite, X-lite, and Solite. For prices in purchasing goods at Mitraindo Online Shop Shop provides wholesale prices and unit prices. In the process of selling at Mitraindo Shop Online Shop through the internet using Tokedia and Shopee. In addition, the store uses a conventional system which means consumers can come directly to see the various products provided.

\section{Instrument Test}

In this test validity and reliability tests are used. A validity test is intended to determine the accuracy of the data about the compatibility between what you want to be measured with the results of the measurement. According to (Sugiyono, 2008), valid means that there are similarities between the data collected and the actual data. While (Ghozali, 2018)) argues, a questionnaire is said to be valid if the questions on the questionnaire are able to reveal something that will be measured by the questionnaire. To conduct a validity test the significance value of 2 tailed is compared with 0.05 with the provisions that if the significance value of 2 is talied $<0.05$, then the instrument is valid; if the significance value of 2 talied $>0.05$, then the instrument is invalid. From the test results obtained for each item statement of all variables obtained significance value of 2 tailed at $0,000<0.05$, thus the instrument is valid. 


\section{Jurnal Administrare: Jurnal Pemikiran Ilmiah dan Pendidikan Administrasi Perkantoran Volume 6 Number 2 July- December 2019. Pages 237-248}

The next test is the reliability unit. The reliability test analysis model used in this study is the Cronbach Alpha model. According to (Ghozali, 2018) "Reliability is a tool to test the consistency of respondents' answers to questions in the questionnaire. A questionnaire is said to be reliable if a person's answer to a question is consistent or stable over time ". The measurements were carried out with Cronbach's Alpha analysis. (Ghozali, 2018) classifies Cronbach's Alpha value, if Cronbach's Alpha value > 0.60, then declared reliable; if Cronbach's Alpha value $<0.60$, then declared unreliable,

The test results are as follows:

Table 2.

Reliability Test Results

\begin{tabular}{lccl}
\hline \multicolumn{1}{c}{ Variabel } & $\begin{array}{c}\text { Cronbach's } \\
\text { Alpha }\end{array}$ & $\begin{array}{c}\text { Alpha Critical } \\
\text { Standards }\end{array}$ & Information \\
\hline Product Quality (X1) & 0,719 & 0,600 & Reliable \\
Price (X2) & 0,683 & 0,600 & Reliable \\
Purchase Decision (Y) & 0,666 & 0,600 & Reliable \\
\hline
\end{tabular}

Based on the results of the above objectives, product quality variable (X1) obtained Cronbach alpha 0,719, price (X2) obtained Cronbach alpha 0,683, and purchase decision (Y) obtained Cronbach alpha 0,666, where all Cronbach alpha values> 0,60. Thus declared reliable

\section{Classic Assumption Test}

The classic assumption test is intended to determine the accuracy of the data. According to (Santoso, 2012), a regression model will be used for forecasting, a good model is a model with minimum forecasting errors. Therefore, a model before use should fulfill a number of assumptions, commonly called classical assumptions. In this study, the classic assumption tests used include normality test, multicollinearity test, autocorrelation test, and heteroskedasticity test. The results are as follows:

A normality test is conducted to test whether, in the regression model, the dependent variable and the independent variable are normally distributed or not normally distributed. The results of the normality test with the Kolmogorov-Smirnov Test are as follows:

Table 3.

Results of Kolmogorov-Smirnov normality

\begin{tabular}{ll|l|r|r|r|r}
\hline & Tests of Normality \\
\hline \multicolumn{3}{c}{ Kolmogorov-Smirnov } & \multicolumn{3}{c}{ Shapiro-Wilk } \\
& Statistic & df & Sig. & Statistic & df & Sig. \\
\hline Purchase Decision (Y) & .085 & 96 & .083 & .974 & 96 & .052 \\
\hline a. Lilliefors Significance Correction & & & & & &
\end{tabular}


Based on the test results in the table above obtained significance value $\alpha=0.085$ where the value is greater than the value of $\alpha=0.050$ or $(0.083>0.05)$. Thus, the assumption of the distribution of equations in this test is normal.

Multicollinearity testing is carried out to believe that between independent variables do not have multicollinearity or do not have the effect of correlation between variables determined as models in the study. A multicollinearity test is done by looking at the value of the Tolerance Value and Variance Inflation Factor (VIF). The test results are as follows:

Table 4.

Multicollinearity Test Results with Collinierity Statistics.

\begin{tabular}{lcc}
\hline \multicolumn{1}{c}{ Variabel } & Tolerance & VIF \\
\hline Product Quality (X1) & 0,638 & 1,567 \\
Price (X2) & 0,638 & 1,567 \\
\hline
\end{tabular}

Based on the test results in the table above the tolerance value of each independent variable is $0.638<1.0$ and the value of Variance Inflation Factor (VIF) of $1.567<10$, thus this regression model does not occur multicollinearity.

Autocorrelation testing is used to determine whether there is any correlation between the sample members. Testing is done with the Darbin-Watson test (DW test). The test results are as follows:

Table 5.

Autocorrelation Test Results

\begin{tabular}{ll|rrrrr}
\multicolumn{7}{c}{ Model Summary $^{\mathbf{b}}$} \\
\hline Model & $\mathrm{R}$ & R Square & \multicolumn{2}{c}{$\begin{array}{c}\text { Adjusted R } \\
\text { Square }\end{array}$} & $\begin{array}{c}\text { Std. Error of the } \\
\text { Estimate }\end{array}$ & Durbin-Watson \\
\hline 1 & $.700^{\mathrm{a}}$ & .490 & .479 & 2.51341 & 1.998 \\
\hline
\end{tabular}

a. Predictors: (Constant), Price (X2), Product Quality (X1)

b. Dependent Variable: Purchase Decision (Y)

The test results in the table above obtained Durbin-Watson value of 1,998 values are between the interval 1,550 - 2,460. Thus the regression model stated no autocorrelation disorders.

Heteroscedasticity testing is intended to test whether in a regression model residual variance inequality occurs. The test results are as follows:

Table 6.

Heteroskedasticity Test Results with the Glejser Test Model

Coefficients $^{\mathrm{a}}$

\begin{tabular}{|c|c|c|c|c|c|}
\hline \multirow[b]{2}{*}{ Model } & \multicolumn{2}{|c|}{$\begin{array}{c}\text { Unstandardized } \\
\text { Coefficients }\end{array}$} & \multirow{2}{*}{$\begin{array}{c}\text { Standardized } \\
\text { Coefficients } \\
\text { Beta } \\
\end{array}$} & \multirow[b]{2}{*}{$\mathrm{t}$} & \multirow[b]{2}{*}{ Sig. } \\
\hline & B & Std. Error & & & \\
\hline $\begin{array}{ll}1 & \text { (Constant) }\end{array}$ & 1.415 & 1.795 & & .788 & .432 \\
\hline Product Quality (X1) & -.050 & .051 & -.124 & -.966 & .337 \\
\hline Price $(\mathrm{X} 2)$ & .064 & .053 & .154 & 1.200 & .233 \\
\hline
\end{tabular}

a. Dependent Variable: Purchase Decision (Y) 


\section{Jurnal Administrare: Jurnal Pemikiran Ilmiah dan Pendidikan Administrasi Perkantoran Volume 6 Number 2 July- December 2019. Pages 237-248}

The test results using the glacier test obtained Sig. $>0.05$. Therefore, the regression model does not have heteroscedasticity disorder.

\section{Descriptive Analysis}

This test used to determine the minimum and maximum scores, mean scores, and standard deviations of each variable. The results are as follows:

Table 7.

Results of Descriptive Statistics Analysis

Descriptive Statistics

\begin{tabular}{lr|r|r|r|r}
\hline & N & Minimum & Maximum & Mean & Std. Deviation \\
\hline Product Quality (X1) & 96 & 32.00 & 48.00 & 38.3125 & 3.81772 \\
\hline Price (X2) & 96 & 30.00 & 45.00 & 38.3958 & 3.70058 \\
\hline Purchase Decision (Y) & 96 & 32.00 & 46.00 & 39.1667 & 3.48128 \\
\hline Valid N (listwise) & 96 & & & & \\
\hline
\end{tabular}

Product quality obtained a minimum variance of 32 and a maximum variance of 48 with a mean score of 3.83 with a standard deviation of 3.817. Prices obtained a minimum variance of 30 and a maximum variance of 45 with a mean score of 3.83 with a standard deviation of 3.700 . The purchase decision obtained a minimum variance of 32 and a maximum variance of 46 with a mean score of 3.91 with a standard deviation of 3.481 .

\section{Multiple Linear Regression Analysis}

This regression test is intended to determine changes in the dependent variable if the independent variable changes. The test results are as follows:

Table 8.

Results of Multiple Linear Regression Testing

\begin{tabular}{|c|c|c|c|c|c|c|}
\hline \multicolumn{7}{|c|}{ Coefficients $^{\mathrm{a}}$} \\
\hline \multirow{2}{*}{\multicolumn{2}{|c|}{ Model }} & \multicolumn{2}{|c|}{$\begin{array}{l}\text { Unstandardized } \\
\text { Coefficients }\end{array}$} & \multirow{2}{*}{$\begin{array}{c}\text { Standardized } \\
\text { Coefficients } \\
\text { Beta } \\
\end{array}$} & \multirow[b]{2}{*}{$\mathrm{t}$} & \multirow[b]{2}{*}{ Sig. } \\
\hline & & $\mathrm{B}$ & Std. Error & & & \\
\hline 1 & (Constant) & 11.421 & 2.954 & & 3.866 & .000 \\
\hline & Product Quality (X1) & .378 & .085 & .414 & 4.467 & .000 \\
\hline & Price $(\mathrm{X} 2)$ & .346 & .087 & .368 & 3.965 & .000 \\
\hline
\end{tabular}

a. Dependent Variable: Purchase Decision (Y)

Based on the test results in the above table, the regression equation $\mathrm{Y}=11.421+0.378 \mathrm{X} 1+$ $0.436 \mathrm{X} 2$ is obtained. A constant of 11,421 means that if there is no product quality and price, then there is a purchase decision value of 11.421 points. Product quality regression coefficient of 0.378 , this number is positive, meaning that every time there is an increase in product quality by 0.378 , purchasing decisions will also increase by 0.378 points. The price regression 
coefficient of 0.436 , this number is positive meaning that every time there is an increase in the price of 0.436 , the purchasing decision will also increase by 0.436 points.

\section{Correlation Coefficient Analysis}

Correlation coefficient analysis is intended to determine the degree of relationship strength of the independent variables on the dependent variable either partially or simultaneously. The test results are as follows:

Table 9.

Correlation Coefficient Test Results on Product Quality Against Purchasing Decisions.

Correlations $^{\text {b }}$

\begin{tabular}{llr|r}
\hline & & $\begin{array}{c}\text { Product } \\
\text { Quality (X1) }\end{array}$ & $\begin{array}{r}\text { Purchase Decision } \\
\text { (Y) }\end{array}$ \\
\hline Product Quality (X1) & Pearson Correlation & 1 & $.635^{* *}$ \\
\cline { 2 - 4 } & Sig. (2-tailed) & & .000 \\
\hline Purchase Decision (Y) & Pearson Correlation & $.635^{* *}$ & 1 \\
\cline { 2 - 5 } & Sig. (2-tailed) & .000 & \\
\hline
\end{tabular}

**. Correlation is significant at the 0.01 level (2-tailed).

b. Listwise $\mathrm{N}=96$

Based on the test results obtained by a correlation value of 0.635 means that product quality has a strong relationship with purchasing decisions.

Table 10.

Results of Price Correlation Coefficient Testing Against Purchasing Decisions.

Correlations $^{b}$

\begin{tabular}{llr|r}
\hline & & Price (X2) & \multicolumn{1}{c}{$\begin{array}{c}\text { Purchase } \\
\text { Decision (Y) }\end{array}$} \\
\hline Price (X2) & Pearson Correlation & 1 & $.617^{* * *}$ \\
\cline { 2 - 4 } & Sig. (2-tailed) & & .000 \\
\hline Purchase Decision (Y) & Pearson Correlation & $.617^{* *}$ & 1 \\
\cline { 2 - 4 } & Sig. (2-tailed) & .000 & \\
\hline
\end{tabular}

**. Correlation is significant at the 0.01 level (2-tailed).

b. Listwise $\mathrm{N}=96$

Based on the test results obtained by a correlation value of 0.617 means that prices have a strong relationship with purchasing decisions. 
244 Jurnal Administrare: Jurnal Pemikiran Ilmiah dan Pendidikan Administrasi Perkantoran

Volume 6 Number 2 July- December 2019. Pages 237-248

Table 11.

Test Results Correlation Coefficients of Product Quality and Prices Simultaneously Against Purchasing Decisions.

\begin{tabular}{l|c|cr|r}
\multicolumn{5}{c}{ Model Summary $^{\mathbf{b}}$} \\
\hline Model & $\mathrm{R}$ & R Square & $\begin{array}{c}\text { Adjusted R } \\
\text { Square }\end{array}$ & Std. Error of the Estimate \\
\hline 1 & $.700^{\mathrm{a}}$ & .490 & .479 & 2.51341 \\
\hline
\end{tabular}

a. Predictors: (Constant), Price (X2), Product Quality (X1)

b. Dependent Variable: Purchase Decision (Y)

Based on the test results obtained a correlation value of 0.700 means that product quality and price simultaneously have a strong relationship to purchasing decisions.

\section{Analysis of the Coefficient of Determination}

Analysis of the coefficient of determination is intended to determine the percentage of influence of the independent variable on the dependent variable either partially or simultaneously. The test results are as follows:

Table 12.

Test Results for the Determination Coefficient of Product Quality on Purchasing Decisions.

\begin{tabular}{|c|c|c|c|c|}
\hline \multicolumn{5}{|c|}{ Model Summary } \\
\hline Model & $\mathrm{R}$ & R Square & $\begin{array}{l}\text { Adjusted R } \\
\text { Square }\end{array}$ & $\begin{array}{l}\text { Std. Error of the } \\
\text { Estimate }\end{array}$ \\
\hline 1 & $.635^{\mathrm{a}}$ & .403 & .397 & 2.70303 \\
\hline
\end{tabular}

a. Predictors: (Constant), Product Quality (X1)

Based on the test results obtained a determination value of 0.403 means that product quality has an influence contribution of 40.3 to the purchase decision.

Table 13.

Test Results for Price Determination Coefficient on Purchasing Decisions.

Model Summary

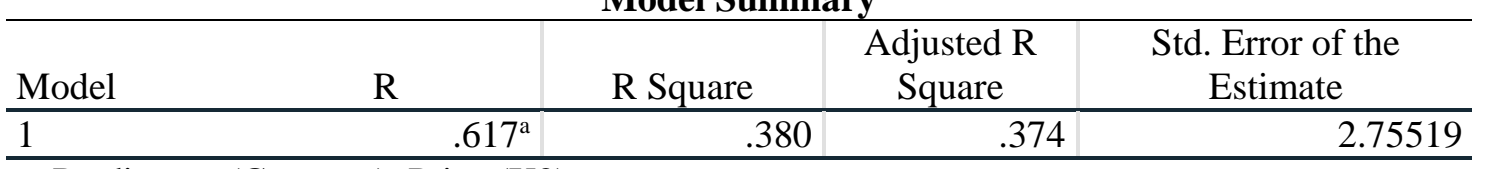

a. Predictors: (Constant), Price (X2)

Based on the test results obtained a determination value of 0.380 means that the price has an influence contribution of $38.0 \%$ to the purchase decision. 
Table 14.

Test Results for the Determination Coefficient of Product Quality and Price on Purchasing Decisions.

\begin{tabular}{|c|c|c|c|c|}
\hline \multicolumn{5}{|c|}{ Model Summary } \\
\hline Model & $\mathrm{R}$ & R Square & Adjusted R Square & $\begin{array}{l}\text { Std. Error of the } \\
\text { Estimate }\end{array}$ \\
\hline 1 & $.700^{\mathrm{a}}$ & .490 & .479 & 2.51341 \\
\hline
\end{tabular}

a. Predictors: (Constant), Price (X2), Product Quality (X1)

b. Dependent Variable: Purchase Decision (Y)

Based on the test results obtained a determination value of 0.490 means that product quality and price simultaneously have an influence contribution of $49.0 \%$ on purchasing decisions, while the remaining $51.0 \%$ is influenced by other factors.

\section{Hypothesis testing}

Hypothesis testing with a t-test is used to find out which partial hypotheses are accepted.

\section{Table 15.}

Results of Hypothesis Test Product Quality on Purchasing Decisions.

\section{Coefficients $^{\mathrm{a}}$}

\begin{tabular}{|c|c|c|c|c|c|c|}
\hline \multirow{2}{*}{\multicolumn{2}{|c|}{ Model }} & \multicolumn{2}{|c|}{$\begin{array}{l}\text { Unstandardized } \\
\text { Coefficients }\end{array}$} & \multirow{2}{*}{$\begin{array}{l}\text { Standardized } \\
\text { Coefficients } \\
\text { Beta } \\
\end{array}$} & \multirow[b]{2}{*}{$\mathrm{t}$} & \multirow[b]{2}{*}{ Sig. } \\
\hline & & $\mathrm{B}$ & Std. Error & & & \\
\hline \multirow[t]{2}{*}{1} & (Constant) & 16.975 & 2.797 & & 6.070 & .000 \\
\hline & Product Quality (X1) & .579 & .073 & .635 & 7.974 & .000 \\
\hline
\end{tabular}

a. Dependent Variable: Purchase Decision (Y)

Based on the test results in the table above, the value of $t_{\text {count }}>t_{\text {table }}$ or $(7.974>1.986)$ is obtained, thus the first hypothesis proposed that there is a significant influence on product quality on purchasing decisions is accepted.

Table 16.

Results of Price Hypothesis Tests on Purchasing Decisions.

Coefficients $^{\mathbf{a}}$

\begin{tabular}{|c|c|c|c|c|c|c|}
\hline \multirow{2}{*}{\multicolumn{2}{|c|}{ Model }} & \multicolumn{2}{|c|}{$\begin{array}{l}\text { Unstandardized } \\
\text { Coefficients }\end{array}$} & \multirow{2}{*}{$\begin{array}{c}\text { Standardized } \\
\text { Coefficients } \\
\text { Beta }\end{array}$} & \multirow[b]{2}{*}{$\mathrm{t}$} & \multirow[b]{2}{*}{ Sig. } \\
\hline & & B & Std. Error & & & \\
\hline \multirow[t]{2}{*}{1} & (Constant) & 16.894 & 2.946 & & 5.734 & .000 \\
\hline & Price (X2) & .580 & .076 & .617 & 7.594 & .000 \\
\hline
\end{tabular}

a. Dependent Variable: Purchase Decision $(\mathrm{Y})$ 


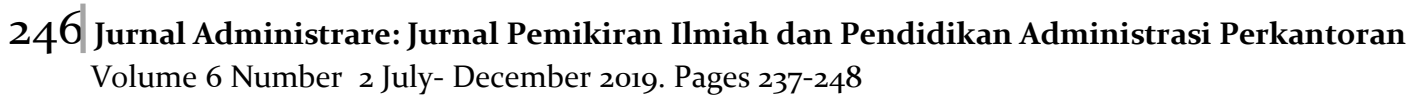

Based on the test results in the above table, the value of $t_{\text {count }}>t_{\text {table }}$ or (7.594>1.986) is obtained, thus the second hypothesis it is proposed that there is a significant influence between price and purchase decision.

Hypothesis testing with the F test is used to find out which simultaneous hypotheses are accepted.

Table 17.

Hypothesis Test Results of Product Quality and Prices Against Purchasing Decisions.

\begin{tabular}{llr|r|r|r|r}
\multicolumn{7}{c}{ ANOVA $^{\mathbf{a}}$} \\
\hline Model & \multicolumn{1}{c}{ Sum of Squares } & \multicolumn{1}{c}{ df } & Mean Square & \multicolumn{1}{c}{ F } & \multicolumn{1}{c}{ Sig. } \\
\hline \multirow{2}{*}{1} & Regression & 563.831 & 2 & 281.915 & 44.626 & $.000^{\mathrm{b}}$ \\
\cline { 2 - 8 } & Residual & 587.502 & 93 & 6.317 & & \\
\cline { 2 - 8 } & Total & 1151.333 & 95 & & & \\
\hline
\end{tabular}

a. Dependent Variable: Purchase Decision (Y)

b. Predictors: (Constant), Price (X2), Product Quality (X1)

Based on the test results in the table above, the calculated $F_{\text {count }}>F_{\text {table }}$ or $(44.662>2,700)$, thus the third hypothesis proposed that there is a significant influence between product quality and price on the purchase decision is accepted.

\section{CONCLUSION}

Based on the results of the study, product quality has a significant effect on purchasing decisions a correlation value of 0.635 or strong with a contribution of 40.3. Hypothesis testing obtained $t_{\text {count }}>t_{\text {table }}$ or $(7.974>1.986)$. Thus there is a significant influence between product quality on purchasing decisions at the South Tangerang Mitraindo Shop Online. Price has a significant effect on purchasing decisions with a correlation value of 0.617 or strong with an influence contribution of $38.0 \%$. Hypothesis testing obtained $t_{\text {count }}>t_{\text {table }}$ or $(7.594>1.986)$. Thus there is a significant influence between price on purchasing decisions at the South Tangerang Mitraindo Shop Online. Product quality and price have a significant effect on purchasing decisions with a correlation value of 0.700 or strong with a contribution of $49.0 \%$ while the remaining $51.0 \%$ is influenced by other factors. Hypothesis testing obtained the value of $\mathrm{F}_{\text {count }}>$ $F_{\text {table }}$ or $(44,626>2,700)$. Thus there is a significant effect between product quality and price simultaneously on purchasing decisions at Mitraindo South Tangerang Online Shop.

\section{REFERENCES}

Amrullah, A. R., \& Agustin, S. (2016). Pengaruh Kualitas Produk Harga dan Citra Merek terhadap Keputusan Pembelian Honda Beat. Jurnal Ilmu Dan Riset Manajemen Sekolah Tinggi Ilmu Ekonomi Indonesia (STIESIA) Surabaya ISSN: 2461-0593.

Arikunto, S. (2006). Prosedur Penelitian Suatu Tindakan Praktik. Jakarta: Rineka Cipta.

Dabhilkar, M. (2011). Trade-offs in make-buy decisions. Journal of Purchasing and Supply Management, 17(3), 158-166. https://doi.org/https://doi.org/10.1016/j.pursup.2011.04.002 
Dinopoulos, E., Kalyvitis, S., \& Katsimi, M. (2020). Variable export price elasticity, product quality, and credit constraints: Theory and evidence from Greek firms. Journal of International Money and 102135. https://doi.org/https://doi.org/10.1016/j.jimonfin.2020.102135

Ferrara, I., Missios, P., \& Yildiz, H. M. (2019). Product quality, consumption externalities, and the role of National Treatment. European Economic Review, 117, 1-35. https://doi.org/https://doi.org/10.1016/j.euroecorev.2019.04.005

Ghozali, I. (2018). Aplikasi Analisis Multivariate dengan Program IBM SPSS 25.

Kotler, P. \& Armstrong, G. (2008). Prinsip-Prinsip Pemasaran. Edisi 12. Jilid 1. Manajemen Pemasaran.

Kotler. (2013). Manajemen Pemasaran Jilid 2. In Penerbit Erlangga.

Kotler dan Amstrong. (2008). Prinsip-Prinsip Pemasaran Jilid I. In Erlangga.

Kotler, P., \& Keller, K. L. (2015). Marketing Mangement. In Pearson Edition Limited.

Laussel, D., Long, N. Van, \& Resende, J. (2020). Quality and price personalization under customer recognition: A dynamic monopoly model with contrasting equilibria. Journal of $\begin{array}{lllll}\text { Economic Dynamics and } & 103869 .\end{array}$ https://doi.org/https://doi.org/10.1016/j.jedc.2020.103869

Li, D., Nagurney, A., \& Yu, M. (2018). Consumer learning of product quality with time delay: Insights from spatial price equilibrium models with differentiated products. Omega, 81, 150-168. https://doi.org/https://doi.org/10.1016/j.omega.2017.10.007

Lubis, D. I. D., \& Hidayat, R. (2017). Pengaruh Citra Merek dan Harga terhadap Keputusan Pembelian pada Sekolah Tinggi Ilmu Manajemen Sukma Medan. In Jurnal Ilman. https://doi.org/2355-1488

Maulana, S. M., Susilo, H., \& Riyadi. (2015). Implementasi E-Commerce Sebagai Media Penjualan Online. Jurnal Administrasi Bisnis.

Nair, G. K. (2019). Dynamics of pricing and non-pricing strategies, revenue management performance and competitive advantage in hotel industry. International Journal of Hospitality Management, 82, 287-297. https://doi.org/https://doi.org/10.1016/j.ijhm.2018.10.007

Narwal, P., \& Nayak, J. K. (2020). How consumers form product quality perceptions in absence of fixed posted prices: Interaction of product cues with seller reputation and third-party reviews. Journal of Retailing and Consumer Services, 52, 101924. https://doi.org/https://doi.org/10.1016/j.jretconser.2019.101924

Peterson, D. (2000). Introduction to E-commerce. In Financial Services Information Systems. https://doi.org/10.1201/9780203997611

Prasastiningtyas, T. R. (2016). Pengaruh Citra Merek, Kualitas Produk, Dan Harga Terhadap Keputusan Pembelian Kartu Seluler. Jurnal Ilmu Dan Riset Manajemen.

Putra, P. K., \& Santoso, P. (2013). Aplikasi Toko Tas Online Berbasis Android. Dimensi Teknik 

248 Jurnal Administrare: Jurnal Pemikiran Ilmiah dan Pendidikan Administrasi Perkantoran
Volume 6 Number 2 July- December 2019. Pages 237-248

Elektro.

Rahmawati, N., \& Mulyono, H. (2016). Analisis dan Perancangan Sistem Informasi Pemasaran berbasis Web pada Toko Billy. Jurnal Manajemen Sistem Informasi.

Ritnamkam, S., \& Sahachaisaeree, N. (2012). Package Design Determining Young Purchasers 'Buying Decision: A Cosmetic Packaging Case Study on Gender Distinction. Procedia Social and Behavioral Sciences, 38, 373-379. https://doi.org/https://doi.org/10.1016/j.sbspro.2012.03.359

Santoso, S. (2012). Panduan Lengkap SPSS Versi 20. In PT Elex Media Komputindo.

Sheats, J. L., Middlestadt, S. E., Ona, F. F., Juarez, P. D., \& Kolbe, L. J. (2013). Understanding African American Women's Decisions to Buy and Eat Dark Green Leafy Vegetables: An Application of the Reasoned Action Approach. Journal of Nutrition Education and Behavior, 45(6), 676-682. https://doi.org/https://doi.org/10.1016/j.jneb.2013.07.013

Sugiyono. (2008). Metode Penelitian Kuatintatif, Kualitatif dan R\&D. In Alfabeta. https://doi.org/2008

Sugiyono. (2010). Metode Penelitian Bisnis. Pendekatan Kuantitatif, kualitatif dan R \& D. Bandung: Alfabeta.

Tjiptono. (2007). Strategi Pemasaran, edisi kedua.

Walch, R. E. (2009). Electronic commerce. In Key Aspects of German Business Law (Fourth Edition): A Practical Manual. https://doi.org/10.1007/978-3-540-68577-7_24 